\title{
砂のような粒状体の構造，応力，運動則に関する準巨視的考察

\author{
A SUBMACROSCOPIC CONSIDERATION ON FABRIC, STRESS AND KINEMATICS \\ OF GRANULAR MATERIALS LIKE SAND
}

\author{
飛田善雄*・柳澤栄司** \\ By Yoshio TOBITA and Eiji YANAGISAWA
}

\begin{abstract}
The contact tensor and modified stress tensor for granular materials are proposed in order to account for the internal fabric state and internal stress state. The fundamental features of these tensors are discussed and the evolutions of them for monotonic and cyclic loadings are examined. The significance of them as internal variables for the description of mechanical behavior of granular materials is discussed. The simple kinematics of granular materials is proposed and the dilatant behavior is discussed. The spin tensor, which has been neglected in the kinematics of granular materials, is also studied.
\end{abstract}

\section{1. まえがき}

砂のような粒状体の変形・破壊挙動は, 試料作成方法 および応力履歴に大きく左右されることが知られてい る.このような挙動を取り扱うためには, 粒状体の内部 構造および微視的内部応力を考える必要がある.

本研究では, ファブリックテンソルの一種であるコン タクト・テンソルを定義し, それに基づいて, 修正応力 という新しい応力を導入する. 単調載荷時, 繰り返し載 荷時について, この 2 つのテンソルの基本的移行則につ いて考察し, 砂のような粒状体の変形特性を理解するう えで，重要な役割を果たすことを示す.

また, 砂のような粒状体の運動則について考察し, 成 分を弾性的成分, 構造変化による非可逆成分, 粒子間の すべりによる成分に分離し，それぞれについて定式化を 行い, 特に, ダイレタンシー挙動について説明を加える.

本研究は, 主に, 構造テンソルの主軸と応力の主軸が 一致する場合について考察するが，この 2 つのテンソル の共軸性が成立しないときには, 変形速度テンソルのみ

* 正会員 工修 東北大学助手 工学部土木工学科 (現・八戸工業大学講師 工学部土木工学科) ( ( 031 八戸市大字妙字大開 88-1)

** 正会員 工博 東北大学教授 工学部土木工学科 （厂980 仙台市荒巻字青葉）
ならず, スピン・テンソルも, 必然的に, 生ずることを 明らかにする. この問題は, 初期異方性, 誘導異方性, 主応力回転時の塑性変形挙動および客観性の原理を満足 する構成式を考えるうえで重要になる.

本論文における変形特性の議論は, ひずみ硬化時のも のに限り, ピーク以降のひずみ軟化は取り扱わない.

本論文を通して, 直交デカルト座標を用い, 特に断り のない限り, 繰り返し指標に関する通常の総和規約を用 いる. 土質工学の慣例に従い, 王縮を正（座標軸の負の 方向）に考えるものとする.

本研究では, 直接的には, 粒子レベルの微視的運動は 考えずに, 粒子の運動を平均化したテンソル量を取り扱 う. そのため, 金属塑性論においてすべり変形が準巨視 的性質ととらえられていることにならい, 標題のように 名づけた。

\section{2. 既往の研究との関連}

本研究の背後には, 数多くの優れた研究があるが, こ こでは, 直接関連するもののみを取り上げる.

微視的な観点から,ダイレタンシー挙動を説明した研 究に, Newland \& Allely') のものがある.これは, 粒 子レベルで生ずる“すべり”は，巨視的なすべり面から， 逸脱しているためにダイレタンシーが生ずるとするもの 
であり，同時に，砂のような粒状体が粒子の固有摩擦角 を越えた内部摩擦角を支持できることを明確に示してい る.このモデルは, 物理的に理解しやすく, 多くの研究 者に受け入れられた。たとえば, Matsuoka ${ }^{2)}$ は，仮想 すべり面上 (以下，モビライズド面と記す) での力のつ り合いと運動を微視的に考察することにより, 独自の構 成式を導き, 三主応力状態へ発展させている.

これに対して, Horne ${ }^{3)}$ は, Rowe のストレス・ダイ レタンシー式を詳細に検討し，粒状体のひずみ硬化は, 粒子群のすべりによって生ずる異方性の増大によるもの であることを示した．この考え方は，三軸圧縮試験の各 段階で, 砂の内部構造を樹脂により固結して, その薄片 を䫓微鏡を用いて観察する方法を用いて Oda ${ }^{4)}$ により， また, 光弾性粒子を用いた二次元的実験を用いて, 小西5 により検証された。

この両者の長所を挙げれば，すべり面における運動を 考えるモデルは運動則の数学的表現が容易であり, 後者 の異方性を重要視するモデルは，ひずみ硬化特性を適切 に表現することである．本研究では，両者のアプローチ のもつ長所を利用することにより，砂のような粒状体の 運動則を提案している.

砂の内部構造の数学的表現は, Satake ${ }^{6)}$, Oda et al. ${ }^{7)}$, Kanatani ${ }^{8)}$ らにより与えられ，ファブリック・テンソル と名づけられた。これらの研究では, 塑性変形中に生ず るファブリック・テンソルの移行則は与えられていな い. 本研究では，簡単な移行則を与え，その結果をもと にして, 単調載荷時, 繰り返し載荷時の変形挙動を考察 している.

\section{3. コンタクトテンソルと修正応力}

\section{（1）コンタクトテンソル}

ファブリックテンソルについては, 前記の優れた報告 があるので，ここでは次章以下の議論に必要な関係式の みを取り上げることにする，一般に，砂のような粒状体 が外力を受けると，粒子の接点は，力を伝えるものとそ うでないものの 2 つに分けることができる5). 力を伝え る接点は，特殊な構造を形成し，柱) あるいはチェイン $\left(\text { 鎖 }^{5}\right)^{5}$ とよばれているが，以下では，簡単に，構造と記 すことにする. 以下の議論は, 基本的には, Oda et al. ${ }^{7)}$ にならっている.

いま，十分な数の粒子を含む体積 $V$ を考える．おの おのの接点に対して, その接触面積 $d S^{(\infty)}$ とその法線べ クトル $\boldsymbol{n}^{(\alpha)}$ を求める. Fig. 1 に示す単位球上の単位法線 ベクトル $\boldsymbol{n}$ を有する微小面素 $d \Omega$ 上に, $\boldsymbol{n}$ の法線ベク トルをもつ接点をすべて集め, その総接触面積を $C(\boldsymbol{n})$ で表わす。

ここで, 法線ベクトルレをもつ任意の面への接触面

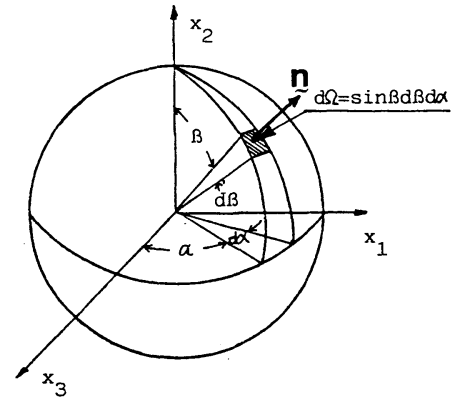

Fig. 1 Elementary solid angle.

積の投影を考える. 法線ベクトル $\boldsymbol{n}$ をもつ接触面積は， $d S^{(v)}=C(\boldsymbol{n})(\boldsymbol{n} \cdot \boldsymbol{\nu}) d \Omega$ と投影される. : $\boldsymbol{n} \cdot \boldsymbol{\nu}$ は内積を表 わす. $\boldsymbol{n} \cdot \boldsymbol{\nu}>0$ について考える. この投影された接触面 積に, 法線ベクトル $\boldsymbol{n}$ を与えて, 次式で定義されるべ クトルを求める.

$$
d S_{i}^{(v)}=C(\boldsymbol{n})(\boldsymbol{n} \cdot \boldsymbol{\nu}) n_{i} d \Omega
$$

式 (1) は， $\nu$ 面の粒子間力を伝達するのに有効と考 えられる， $\nu$ 面に投影された接触面積に，その方向を与 えたものである. 式 (1) をすべての面素 $d \Omega$ について 求め, これを積分し, 領域 $V$ および積分の際に生ずる $\int_{\Omega_{1 / 2}} d \Omega=2 \pi$ の影響を除くと, 単位体積当たりの $\nu$ 面に 投影された接触面積の大きさをもち，かつその投影され た接触面の平均的な方向を与えるべクトルが得られる.

$$
S_{i}^{(\nu)}=\frac{1}{2 \pi V} \int_{0_{1 / 2}} C(n)(n \cdot \nu) n_{i} d \Omega
$$

ここに, $\Omega_{1 / 2}$ は $\boldsymbol{n} \cdot \boldsymbol{\nu} \geqq 0$ についての積分を表わす.式(2) で定義されるベクトルを $\nu$ 面の単位体積当たりの接触

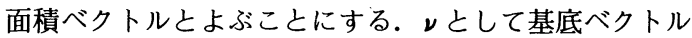
$\boldsymbol{e}_{i}$ をとり, $\boldsymbol{e}_{i}$ 面での単位体積当たりの接触面積ベクト ル $S_{j}^{\left(e_{i}\right)}$ を求めると, 次のようになる.

$$
S_{j}^{(e t)}=\frac{1}{2 \pi V} \int_{\Omega_{1 / 2}} C(\boldsymbol{n}) n_{i} n_{j} d \Omega
$$

ここで, $\boldsymbol{n} \cdot \boldsymbol{e}_{\boldsymbol{i}}=n_{\boldsymbol{t}}$ を用いている. 式 $(3)$ は $\boldsymbol{e}_{\boldsymbol{i}}$ 面の単 位体積当たりの接触面積ベクトルの $j$ 成分を表わす. これを,

$$
C_{i j}=S_{j}^{\left(e_{i}\right)}
$$

と簡単に記す。（2）と（3）を比較すれば，わかるよ うに，任意の面の接触面積ベクトルは $C_{i j}$ を用いて，次 のようになる.

$$
S_{i}^{(v)}=C_{j i} \nu_{j} \cdots
$$

以下， $C_{j i}$ をコンタクトテンソルとよぶことにする。 応力を定義するためには, 連続体力学の応力ベクトル に相当する， $\boldsymbol{\nu}$ 面を通して伝達される粒子間力の合力を 考える必要がある．このためには $\boldsymbol{\nu}$ 面を通して伝達さ れる粒子間力を一度だけ数えるような面の厚さを考える 必要がある. 個々の粒子間力についてその厚さは異なる 


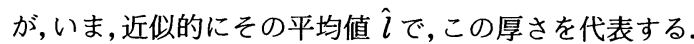
このとき，単位面積当たり（厚さ $\hat{l}$ を有する）の接触面 積ベクトルは $C_{i j}$ を用いて次のように記述できる.

$$
S_{i}^{*(v)}=\hat{l} C_{k i} \nu_{k}
$$

従来の研究の多くは, 接点の法線方向の分布を, 確率 密度関数 $E(n)$ を用いて表現している。 $\nu$ 面に関して計 測した法線方向の分布に関する確率密度関数を $E^{(n)}(n)$ と表わすとき， $E^{(v)}(\boldsymbol{n})$ と $E(\boldsymbol{n})$ の関係は， $\boldsymbol{\nu}$ 面に投影 される接触点の等值性を用いて, Oda et al. ${ }^{7)}$ により, 次のように求められている。

$$
E^{(\nu)}(\boldsymbol{n})=\frac{E(\boldsymbol{n}) \boldsymbol{n} \cdot \nu}{\int_{\Omega_{1 / 2}} E(\boldsymbol{n}) \boldsymbol{n} \cdot \nu d \Omega}
$$

ここに, $\boldsymbol{n} \cdot \boldsymbol{v}$ は内積を表現する.

\section{（2）変換テンソルの定義と变換面の物理的意味}

塑性変形中に粒状体はその内部構造を変える. 異方的 な構造を理想的な等方構造と比較することにより，変換 テンソル $F_{i j}$ を定義する．この理想的な粒状体の，単位 体積当たりの接触面積を $C_{0}^{*}$ と表現するとき各座標方向 の値は,

$$
\rho_{i}=\rho_{0}=C_{0}^{*} / 3 \quad i=1,2,3
$$

となる. 変換テンソル $F_{i j}$ を次のように与える.

$$
F_{i j}=C_{i j} / \rho_{0}
$$

式 $(9)$ による変換テンソルを用いて, 次のような微小 面素の変換を考える.

$$
d A_{i}^{*}=F_{i k} d A_{k}
$$

ここに, $d A_{i}^{*}$ は変換後の微小面素, $d A_{k}$ は変換前の粒 状体を連続体之みなしたときの微小面素を意味する.

式（10）の変換のもつ幾何学的意味を座標軸をコンタ クト・テンソルの主軸と一致させて考察する.このとき, 式（10）は, 式（8）を用いて

$$
\rho_{0} d A_{i}^{*}=C_{(i)} d A_{(i)}(\text { 和は取らない) }
$$

この式の意味することは，変換後のコンタクト・テンソ ルの值は各方向とも $\rho_{0} に$ 等しく, また, 変換前後の単 位面積当たりの接触面積ベクトルは変化しないというこ とである. すなわち，基準值をもつ等方構造になるよう に，接触面積の大きい面は拡大し，小さい面は縮小する ことになる.

\section{（3）修正応力の定義とその物理的意味}

式（10）により得られる新しい面上での応力を定義す る. Fig. 2 を参照して，実線で示されている四面体は， 粒状体を連続体之みなして得られるものであり，この面 に対して，われわれは，通常の Cauchy の応カテンソル $\sigma_{i j}$ を定義する．破線で示される四面体は，式（10）に より，変換されたものである．Fig. 2 では， $x_{2}$ 方向の接 触面積が基準値よりも大きく, $x_{1}, x_{3}$ 方向では小さい 場合を想定しているので，各方向の面積は， $x_{2}$ 面が拡

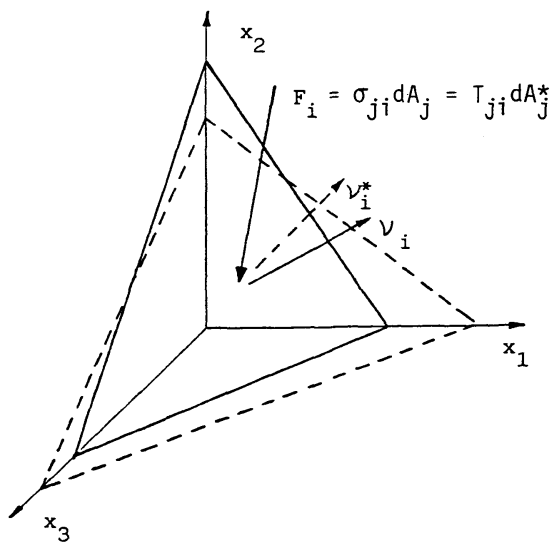

Fig. 2 Transformed plane and Modified stress.

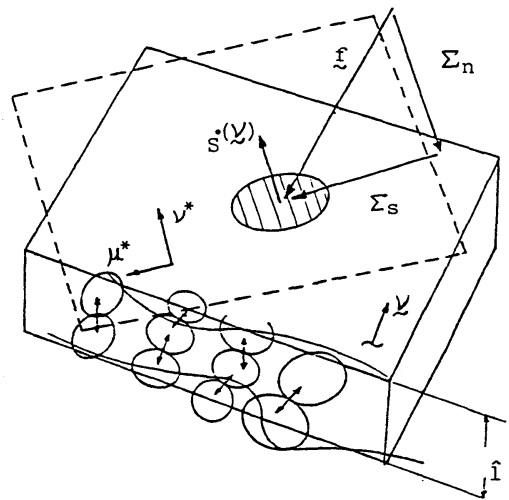

Fig. 3 Physical meanings of Modified stress.

大され， $x_{1}, x_{3}$ 面が縮小されている.

法線ベクトル $\nu_{i}$ と $\nu_{i}^{*}$ は, 次式で定義される.

$\nu_{i}=d A_{i} / d A, \quad \nu_{i}^{*}=d A_{i}^{*} / d A^{*}$

$d A=\left(d A_{k} d A_{k}\right)^{1 / 2}, d A^{*}=\left(d A_{k}^{*} d A_{k}^{*}\right)^{1 / 2}$

先に定義した粒状体の厚さ $\hat{l}$ を通して, $d A$ を伝達され る粒子間力の和を $F_{i}$ と表わせば，Cauchy の定理によ り,

$F_{i}=\sigma_{j i} d A_{j}$

と表現される．この $F_{t}$ は変換後の面素 $d A^{*}$ を通して伝 達されると考えるとき，新たな応力テンソル $T_{t j}$ を用い $\tau$,

$$
F_{i}=T_{j i} d A_{j}^{*}
$$

とも表現される. 式 (10)，(13)，(14) より， $T_{i j}$ は $\sigma_{t j}$, $F_{i j}$ を用いて，次のように表現される.

$$
T_{i j}=\sigma_{j k}\left(F_{k i}\right)^{-1}, F_{i k}\left(F_{k j}\right)^{-1}=\delta_{i j}
$$

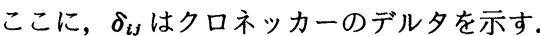

式（15）により定義される応力を，以下，修正応力と よぶことにする．式（15）のように，構造の影響が取り 入れられた応力は, ほかに, Satake'), Nemat Nasser \& Mehrabadhi ${ }^{10)}$ によっても提案されているが，その具 
体的な意味は与えられなかった．次に式（15）による修 正応力の物理的意味を考察する.

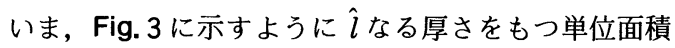
を考える. このときの単位面積当たりの接触面積ベクト ルは式 (6)により与えられる. 注目すべきことは式 (6) 亡式 (10) の変換は同じ法線ベクトルを与えることであ る. すなわち, 式 (12) の $\nu_{i}^{*}$ と式 (6) の $S_{i}^{*(v)}$ では, $\nu_{i}^{*}=S_{i}^{*(v)} /\left\|S_{i}^{*}\right\|,\left\|S_{i}^{*}\right\|=\left(S_{k}^{*(v)} S_{k}^{*(v)}\right)^{1 / 2}$, が成立する.

さて,この $\nu$ 面上の単位面積当たりの接触面積につ いて粒子間力の合力 $f_{i}$ を垂直方向 $\nu^{*}$ に沿う垂直成分 $\Sigma_{n}$ 之接触面に沿う成分 $\Sigma_{s}$ に分離する (Fig. 3 参照). $\Sigma_{s} / \Sigma_{n}$ は, $\nu$ 面の粒子間接点に作用する平均的応力比 であると考えられる.ひずみ硬化過程では, この応力比 が粒子自身の摩擦による抵抗 $\tan \phi_{\mu}$ を越えることはな いものと考えられる.すなわち, $\Sigma_{s} / \Sigma_{n} \leqq \tan \phi_{\mu}$ が成 立すると考えられる. $\boldsymbol{\nu}$ 面に投影された接触面積べクト ルと, 式 (10) による変換面の法線ベクトルが同一方向 を有することにより, 修正応力 $T_{i j}$ により, 変換面上での 接線成分 $T_{s}$ 之垂直成分 $T_{n}$ を求めると, $\left(T_{s}=T_{i j} \nu_{i}^{*} \mu_{j}^{*}\right.$, $\left.T_{n}=T_{i j} \nu_{i}^{*} \nu_{j}^{*}\right)$ 合力ベクトル $f_{i}$ が同一であるので, $T_{s} / T_{n}$ は $\Sigma_{s} / \Sigma_{n}$ に等しくなり, $\nu$ 面上での粒子接点に, 平均 的に，作用する応力比を表現すると考えられる.

粒状体の内部構造が異なれば, 粒状体に作用する応力 $\sigma_{i j}$ が同一であっても, 修正応力 $T_{i j}$ は異なる. 修正応 力は, 特に, ある任意面上でのすべり運動の難易を考え るうえで, 重要な量である. すなわち, 修正応力による $T_{s} / T_{n}$ が低ければ, 粒子のすべり運動は生じにくく, $T_{s} / T_{n}$ が $\tan \phi_{\mu}$ に近ければ生じやすいと考えられる.

\section{4. コンタクト・テンソルと修正応力の移行則}

この章以下では, 物理的意味を明確にするため, 二次 元変形に限って議論する. さらに, 応カテンソル $\sigma_{t j}$ と コンタクト・テンソル $C_{i j}$ の共軸性を仮定し, 主軸方向 に座標軸を選ぶことにする.

\section{（1）単調載荷時の移行則}

現在までに, 二次元的変形状態での粒状体の内部構造 の変化について, アルミ棒の積層体を用いた実験 ${ }^{2}$, 光 弾性粒子を用いた実験5), 11), 12) および離散粒子モデルを用

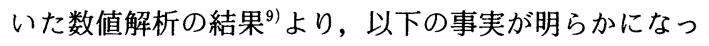
ている.

1）塑性変形中, 新しい接点が最大主応力軸方向に生 じ, 最小主応力軸方向では, 接点は消滅する ${ }^{5), 11)}$.

2) モビライズド面においては，せん断力に抵抗する 接点（正のダイレタンシー角社1)有する接点）が

注 1） 正のダイレタンシー角は, せん断応力に抵抗するとい う意味で正と名づける. 5. で議論するように, 正の ダイレタンシー角は正のダイレタンシーをもたらす。

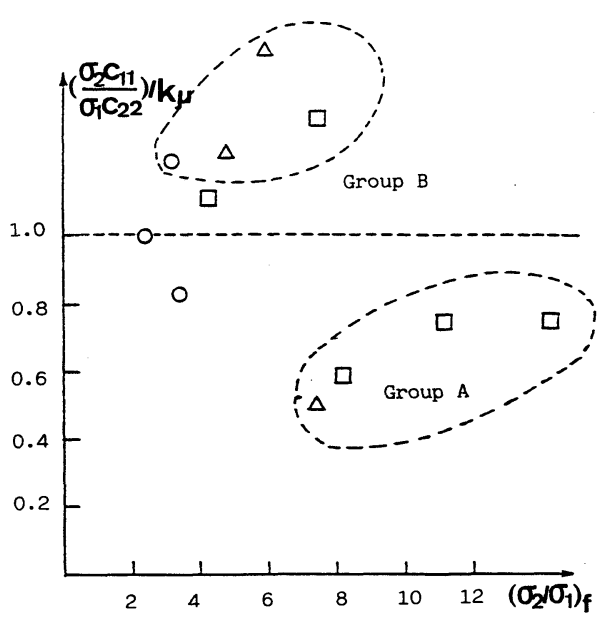

Fig. 4 Relationship between stress ratio and fabric ratio in model tests due to Konishi et al.

増加する2).

3）粒子間力を伝える接点では，粒子間すべりは生 じなく, すべりはむしろ, 力を伝えない接点で生じ る $^{9), 12)}$.

上記実験事実のうち，1）と2）は同じ現象を示唆し ている. 応力主軸と構造主軸の共軸性が成立する場合, 式（6）は次のように表現される.

$S_{i}^{*(v)}=\hat{l} C_{(i)} \nu_{(i)}($ 和は取らない $) \cdots$

$\sigma_{2}>\sigma_{1}$ とすると, モビライズド面上のせん断応力 $\tau$ に 抵抗する接点が増加するということは, $S_{2}^{*(v)}$ が増加し, $S_{1}^{*(v)}$ が減少することを意味している. 式 (16) より, このことが, 最大主軸方向に接点を増加させ, 最小主応 力軸方向に減少することは明らかである.

また，3）の実験事実は，すべりによる構造変化のみ を考えては, 粒状体のひずみ硬化特性が表現できないこ とを示唆している.

これらの実験事実に基づいて，簡単な移行則をコンタ クト・テンソルについて与えることにする. 平均応力 $p^{\prime}\left(p^{\prime}=\left(\sigma_{2}+\sigma_{1}\right) / 2\right)$ は一定に保つものとする.

変形初期においては, 構造変化は, 最大主応力軸方向 のコンタクト・テンソルの值を増加させる. 一方, 最小 主応力軸方向のコンタクト・テンソルは変化しない.こ れは, 最小主応力軸方向には, 圧密までの過程で, すで に十分な構造が発達しており, 外力が減少する過程では, 構造変化は生じないものと考えられるからである.

応力比が増大するに従って, 構造は異方的になり, 粒 子間に作用する微視的応力比も，粒子の固有摩擦係数; $\tan \phi_{\mu}$, に近づいてくる. さらなる外力を支えるために, 一端, 構造変化が生ずると, 粒子間力の再配分が起こり, 粒子がすべりの条件を満足することになる.すべりによ 
る運動は, 最大主応力軸方向に発達した異方的な構造の ために，正のダイレタンシーをもたらす (5. 参照)。こ のため, 最小主応力軸方向の膨張が起こり,この方向の 接触面積が減少することになる．このように高応力比状 態での構造変化は, 最小主応力軸方向にも生ずることに なる。

いま, $\sigma_{2}>\sigma_{1}, C_{2}>C_{1}$ とするとき, 式 (15) の関係 は比の形で, 次のように, 与えられる.

$$
\left(\sigma_{2} / \sigma_{1}\right)=\left(T_{2} / T_{1}\right)\left(C_{2} / C_{1}\right)
$$

前章（3）で議論したように， $\left(T_{2} / T_{1}\right)$ は，任意面で の平均的な接触面積上での応力比と関連するものである から, 粒子間摩擦角 $\phi_{\mu}$ により決定されるある限界値を 有している. 式（17）によれば，その限界値以上の応力 比は，構造の項 $\left(C_{2} / C_{1}\right)$ により支えられることになる. ここでは, $\left(T_{2} / T_{1}\right)$ が限界值に達した後の構造変化は 式（17）により与えられるものと考える.

式 (17) は Oda ${ }^{4}$ が得た実験式

$$
\left(\sigma_{1} / \sigma_{3}\right)=C_{1}\left(S_{1} / S_{3}\right) C_{1}: \text { 定数 }
$$

と同一形式である．式（18）において， $\sigma_{1}$ は三軸圧縮 試験時の最大主応力， $\sigma_{3}$ は最小主応力を示す． $S_{1}$ およ び $S_{3}$ は，それぞれ，接触面積を最大主応力軸が作用す る面,最小主応力軸が作用する面に投影したものである. 以上より，式 (17) と（18）は， $\left(T_{2} / T_{1}\right)$ が限界値に 達した後は同一の現象を表現する式となる.

いま, 式（11）による変換面上での修正応力による応 力比 $T_{s} / T_{n}$ が最も高い面上で粒子間の摩擦係数 $\tan \phi_{\mu}$ に等しいとすると, $\left(T_{2} / T_{1}\right)_{c r}$ は次のように与えられ る永2).

$$
\left(\frac{T_{2}}{T_{1}}\right)_{c r}=\frac{1+\sin \phi_{\mu}}{1-\sin \phi_{\mu}}=k_{\mu}
$$

式（17）の関係を小西5), Konishi et al. ${ }^{11}$ による実験 結果により検証したのが Fig. 4 である. 図に示す $k_{\mu}$ は, 報告にある固有摩擦角を用いて式（19）より求めた．破 壊時において, 主応力軸と構造主軸が一致しない場合に は， $C_{2}$ および $C_{1}$ の代わりに $C_{22}, C_{11}$ を用いた. Fig. 4 をみると，大きく，2つのグループに別れることが理解 できる.グループAは，破壊時においても，粒子間にお いて発揮される摩擦角は, 固有摩擦角よりも低いことを 示している.グループBは，破壊が，構造が十分に発達 しないままで，生じていることを示す。このように，モ デル実験の結果をみると, 式 (17), 式 (19) は, 必ず しも妥当であるとはいえないようである.これは対象と した実験が, きわめて初期異方性の強いものであり，粒

注 2) このことは, まず 1) $T_{2} / T_{1}$ と $C_{2} / C_{1}$ が式 (17), 式 (19) を満足する. 2) 最も修正応力比の高い変換面を求める. 3) その面の応力比が $\tan \phi_{\mu}$ に等しい. という手順で 証明できる。

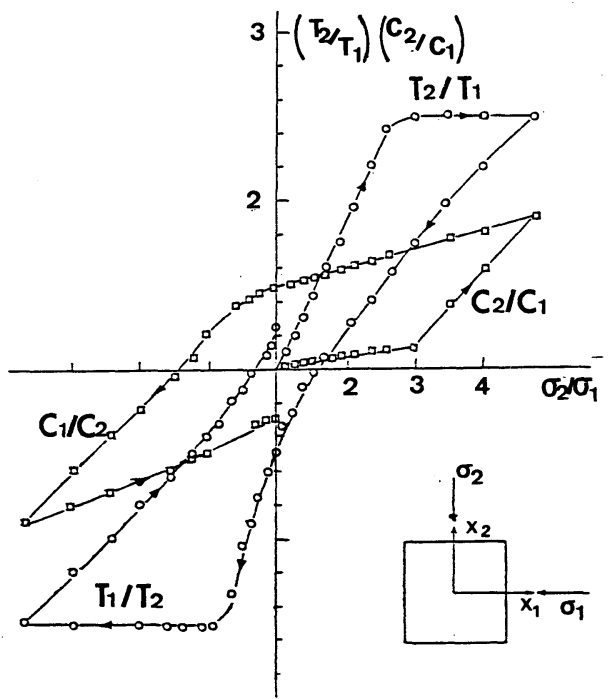

Fig. 5 Evolutions of Contact tensor and modified stress tensor in cyclic large shear.

子形状が偏平であることにより，比較的拘束された状態 で運動が生ずることに関連があるものと思われる．この ことは，粒子の接触面積のみをパラメーターとして，粒 状体の内部構造を代表させ，その力学的挙動を考察する ことには無理があることを示唆している.このように式

(19）方変形後期において，常に成立するという仮定に ついては,疑問が残るが,以下では, 簡単のために,式(17) における $\left(T_{2} / T_{1}\right)$ が限界値に達した後は, 式 (19) を 満足するように，構造変化が生ずるものと考えることに する.

以下, $\left(T_{2} / T_{1}\right)<k_{\mu}$ を低応力比状態, $\left(T_{2} / T_{1}\right)=k_{\mu}$ を 高応力比状態とよぶことにする.

式（15）を微分して主軸状態について記述すると，

$$
d T_{(t)}=\frac{d \sigma_{(i)}}{F_{(i)}}-T_{(i)} \frac{d F_{(i)}}{F_{(i)}}(\text { 和は取らない) }
$$

が得られる. 以下では, 構造変化を生じさせる‘力’は 応力変化の項による修正応力の変化と考え，これを*印 をつけて表わす; $d T_{i}^{*}=d \sigma_{(i)} / F_{(i)}, d T_{i}^{*}$ と $d C_{i}$ の間に 次の簡単な関係を与える.

$d C_{i}=\alpha d T_{i}^{*} ; \alpha:$ 定数

式 $(21)$ は, 同じ応力 $d \sigma_{i}$ が作用しても， $F_{i}$ が発達 していれば, $i$ 方向の構造変化は小さいことを表現して いる.

以上を整理して記述すると, 単調載荷時の移行則は, 「粒状体の変形過程で, 構造変化は, 最大主応力軸方向 では, 式 (21) に基づいて生じ, 最小主応力軸方向の変 化は, 低応力比状態では生じなく, 高応力比状態では, 式（17）および（19）を満足するように生じる. 各変形 段階の修正応力は式 (20) により計算できる.」と仮定 

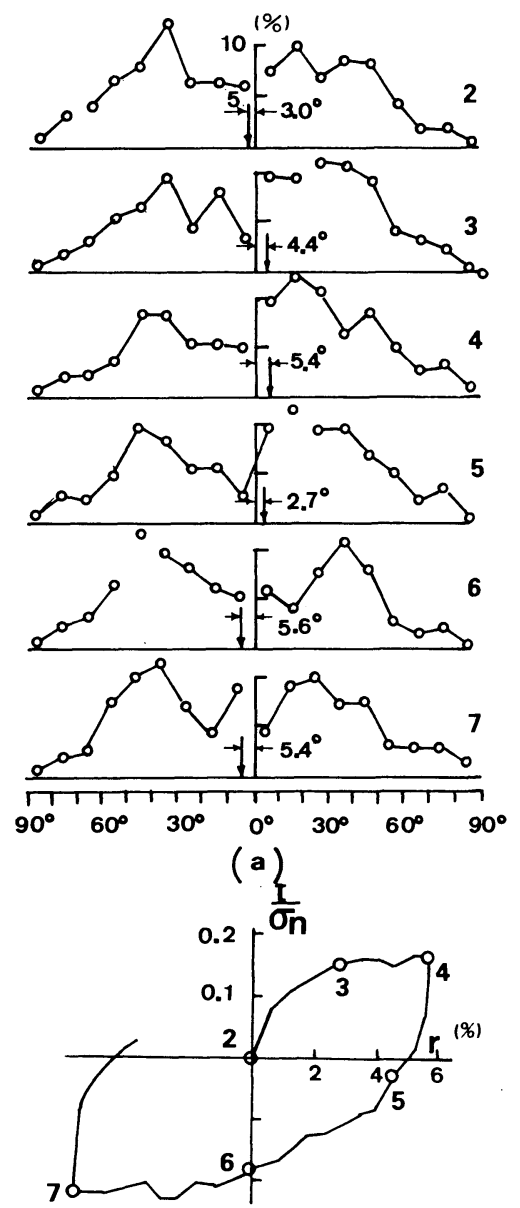

(b)

Fig. 6 Distribution of contact normals on zero extension line in cyclic simple shear test (a) and stress strain relation $(b)$.

することになる．

単調載荷時の実験に基礎を置くこの仮定は, 繰り返し 載荷時においても既往の実験結果と一致する構造変化を 与えることになる。

\section{（2）繰り返し載荷時の移行則}

前節の単調載荷時の移行則に続いて, 繰り返し載荷時 の移行則を検討する. 繰り返し載荷時において注目すべ きことは, 載荷応力比が低いところで, 応力反転が生じ た場合は, 最小主応力軸方向では, 構造変化は生じてい ないので, 除荷時（応力比が減少する過程）では, 構造 変化は生じなく,圧密時よりも大きな応力を受けたとき， すなわち, 応力が完全に反転し, 逆方向載荷になったと きのみ構造変化が生ずることになる．これに対して，高 い応力比から，応力反転が生じた場合は，載荷過程で式

（17）を満足するような構造変化を示すので, 最小主応 力軸方向の構造は弱くなり, 除荷時においても構造変化
が生ずることである．この仮定を次のように表現する。 「構造変化は，次の条件を満足するときに生ずる.

$T_{i}(t)>T_{i}^{*}(t-s)$

ただし，低応力比のとき，

$T_{i}^{*}(t-s)=T_{i}^{\max }(t-s) 0<s<\infty$

高応力比のとき,

$T_{i}^{*}(t-s)=T_{i}(t-d s)$

ここに $T_{i}^{\max }(t-s)$ は過去における最大の修正応力を 示し, $T_{i}(t-d s)$ は, 前段階の修正応力を示す. $T_{i}(t)$ は現在の修正応力である.」

この条件によれば，低応力比での繰り返し載荷では， 過去の応力履歴による構造が保持されるのに対して, 高 応力比の載荷を受けたときには，その直前の構造が比較 の対象亡なる，Fig. 5 は，等方拘束圧 $100 \mathrm{kPa}$ ，平均主 応力を一定としたまま, $\rho_{0}=C_{0}, \alpha=0.002, \phi_{\mu}=26^{\circ}$ と して式 (17)，(19)，(20)，(21)，(22）に基づいて, 繰 り返し載荷を与えたときの修正応力およびコンタクト・ テンソルの運動に関する計算結果である.この図より以 下のことがわかる.

1) 1 回目の載荷を終えて, $\left(\sigma_{2}>\sigma_{1}\right)$ 応力を反転さ せ等方応力状態に戻っても，構造は， $\sigma_{2}$ 軸方向に 卓越した異方向構造 $\left(C_{2} / C_{1}>1\right)$ となっている.

2）修正応力は, 除荷の途中で等方状態となり, 以後 最大主応力軸と最小主応力軸が入れ換わる.

3) 修正応力比は, 逆方向載荷時 $\left(\sigma_{1}>\sigma_{2}\right)$ には, 処 女載荷時よりも急激に変化し，すみやかに，限界値 に達する。

4）構造は, 逆方向載荷時に急激な変化が生ずる.

これらの特性は, 小西の実験結果と一致するものであ る. Fig. 6 は, 小西5)の単純せん断試験の結果より, ゼ 口伸長面 (水平面) 上の接点方向の頻度図を求めたもの である.ここで, 式（16）を用いている. Fig.6より, せん断応力が増加するに従い正のダイレタンシー角が増 えること（このことは $C_{2}$ が増加し， $C_{1}$ が減少するこ とと等価である), その異方的構造は, せん断力 0 になっ ても存在すること, 逆方向載荷時には, 大きな構造変化 が生じて，せん断に抵抗する正のダイレタンシー角を有 する接点が増えることがわかる．Fig. 6 中の矢印は，ゼ 口伸長面の接触面の平均的方向を示すものであり, 式 （5）により計算している.コンタクト・テンソルの移 行則は，この矢印の運動を表わすものであり，Fig. 6 に 示すような分布の変化を示すものではない. すなわち, 平均的な運動のみを指定することができるだけであり， 詳細な情報（分布等）は与えない注3).しかし，コンタ

注 3）これは, 本研究での議論が, 2 階のファブリック・テ ンソルのみを対象としているからであり，さらに高階 のファブリック・テンソルにより分布も表現できる ${ }^{8)}$. 
クト・テンソルの移行則に基づいて, 粒状体の変形挙動 の多くが定性的には説明可能であることが，次章の運動 則に関する議論で明らかにされる。

\section{5. 粒状体の運動則注4)}

一般に，塑性的変形状態を記述するのに，最も便利な ものは速度勾配 : $l_{i j}=v_{i, j}=\partial v_{i} / \partial x_{j}$ である. その対称 成分は変形速度テンソル : $D_{i j}=\left(l_{i j}+l_{j i}\right) / 2$, 反対称テン ソルはスピン・テンソル : $W_{i j}=\left(l_{i j}-l_{j i}\right) / 2$ とよばれて いる.ここに $v_{i}$ は粒子の速度， $x_{j}$ は現在の座標（空間 座標）を示す.

この章での議論も二対元的変形に限定し，さらに応力 主軸と構造主軸の共軸性を仮定する．この条件のもとに 本章では, 変形速度のみを考察することにする(6. 参照).

ここでは, 変形速度テンソルが 3 つの成分からなり, お互いに独立であると考える．すなわち 1）構造変化を 伴わない弾性的成分 $\left.D_{i j}^{e}, 2\right)$ 構造変化による成分 $\left.D_{i j}^{s}, 3\right)$ 粒子の相対的すべりによる成分 $D_{i j}^{p}$

$D_{i j}=D_{i j}^{e}+D_{i j}^{f}+D_{i j}^{p}$

このうち, 弾性成分と構造変化による成分は, 粒状体 の粒子間力の伝達機構之密接に関連するものであるか ら,これをまとめて, 次のように記述する.

$D_{i j}^{*}=D_{i j}^{e}+D_{i j}^{f}$

\section{（1）弾性成分と構造変化成分に関する運動則}

$D_{i j}^{*}$ 成分に対して, 弾性コンプライアンスを用いて, 簡単な関係を仮定する.

$$
D_{i j}^{*}=L_{i j k l}^{e} \dot{T}_{k l}^{*}+L_{i j k l}^{f}<\dot{T}_{k l}^{*}>
$$

ここにく $\dot{T}_{k l}^{*}>$ は, 式 $(22)$ を満足するときのみ值を有 するものとする.

$$
\begin{aligned}
\left\langle\dot{T}_{k l}^{*}\right\rangle & =\dot{T}_{k l}^{*} & & \text { 式 }(22) \text { が満足されるとき } \\
& =0 & & \text { それ以外のとき }
\end{aligned}
$$

座標軸を構造, 応力主軸に一致するように選んで, 弾 性コンプライアンスを等方テンソルとして, 二次元変形 状態を考えると，式（25）はマトリックスの形で,

$$
\begin{aligned}
\left.\left\{\begin{array}{l}
D_{1}^{*} \\
D_{2}^{*}
\end{array}\right\}=\left\{\begin{array}{l}
D_{1}^{e} \\
D_{2}^{e}
\end{array}\right\}+\left\{\begin{array}{l}
D_{1}^{f} \\
D_{2}^{f}
\end{array}\right\}=\frac{1}{E^{e}}\left[\begin{array}{cc}
1 & -\nu^{e} \\
-\nu^{e} & 1
\end{array}\right] \mid \begin{array}{l}
\frac{\dot{\sigma}_{1}}{F_{1}} \\
\frac{\dot{\sigma}_{2}}{F_{2}}
\end{array}\right\} \\
+\frac{1}{E^{f}}\left[\begin{array}{cc}
1 & -\nu^{f} \\
-\nu^{f} & 1
\end{array}\right]\left\{\begin{array}{l}
\left\langle\frac{\dot{\sigma}_{1}}{F_{1}}\right\rangle \\
\left\langle\frac{\dot{\sigma}_{2}}{F_{2}}\right\rangle
\end{array}\right\} \cdots . .
\end{aligned}
$$

となる. 式（27）に基づいて, 弾性的体積変化挙動を $\dot{\sigma}_{2}$ $=-\dot{\sigma}_{1}>0$ について求めてみると,

$$
\operatorname{tr} D_{i j}^{e}=D_{11}^{e}+D_{22}^{e}=\frac{1}{E_{1}} \frac{\left(F_{2}-F_{1}\right)\left(\nu^{e}-1\right)}{F_{2} F_{1}} \dot{\sigma}_{2}
$$

注 4）運動則という用語は，本章の内容を適切には表現しな いが運動に着目するという意味で用いている.
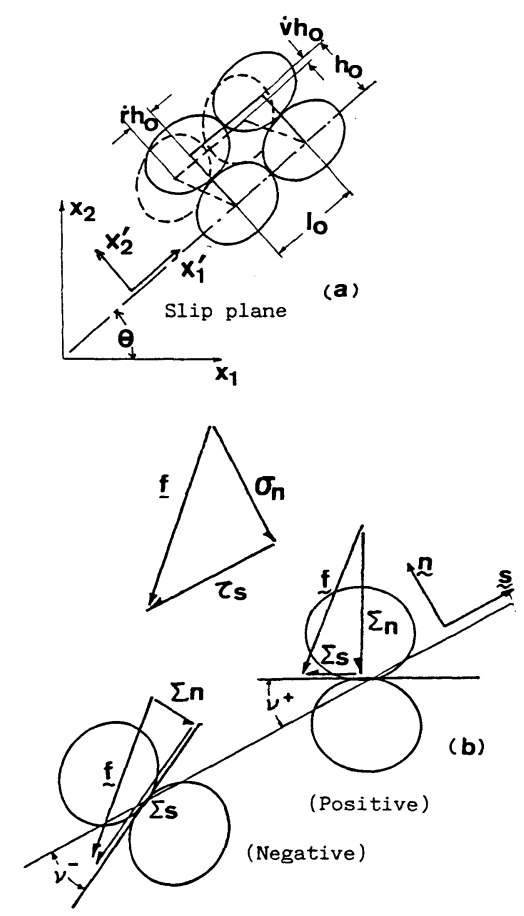

Fig. 7 Simple shear type movements with dilatancy for slippage between particles (a) and the definition of dilatancy angle (b).

となり， $\sigma_{2}>\sigma_{1}$ では一般に, $F_{2}>F_{1}$ と考えることができ， $\left(\nu^{e}-1\right)<0$ であるから, 載荷過程において正のダイレタ ンシーを示すことになる.このような正のダイレタン シ一挙動は, 低応力振幅で, 片振り繰り返し試験を行っ にときに得られる結果と一致するものである.

次に, 高応力比から除荷されたときのダイレタンシー 挙動を計算してみる.このとき, 弾性項のみならず，構 造変化の項も体積変化に寄与するものと考えられる（条 件 (22) を満足する). 最初の載荷 $\dot{\sigma}_{2}=-\dot{\sigma}_{1}>0$ で, コ ンタクト・テンソルが $C_{2}>C_{1}$ になった状態を考える. このとき負のダイレタンシーを与える条件は, $v^{e}=v^{f}$ として,

$\left(1+E^{e} / E^{\jmath}\right) C_{2}>C_{1}$

と与えられ, この条件は, 常に満足される.この高応力 比載荷からの除荷時の負のダイレタンシー特性は, 非排 水繰り返し載荷時のサイクリックモビリティ現象と密接 に関係しており, 重要な性質である。この現象は, 粒状 体の運動をすべりによるものと考えては，説明できない ものである. 本研究では, この除荷時の負のダイレタン シー特性を構造変化という観点から, 定性的に説明した ことになる.

（2）粒子間すべりによる変形速度に関する運動則

粒子間力を伝えている構造に変化が生じれば，粒子間 
力が再配分され，その際，粒子間において，すべりによ る運動が生ずることになる．このすべりによる運動は， 仮想的すべり面を考えることにより，数学的に記述でき る. 本研究でのすべり変形は，モビライズド面のみにお いて生ずるのではなく，その他の面でのすべり運動も併 せて考える. 砂のような粒状体のすべり運動は，すべり 面が結晶学的に決定される多結晶体金属材料と比較すれ ば, 運動の自由度は大きく,ひずみ硬化過程においては, すべり面の存在を物理的観点から正当化することは難し いものと思われる. しかし，ここでは，数学的簡便さを 保持するために，仮想的すべり面を導入する.

いま，すべり運動が Fig. 7 に示すように，ダイレタン シーを伴った単純せん断型の運動を示すと考える.すべ り面に沿って,図に示すような, 局所座標系 $x_{i}^{\prime}$ を考える. 基準座標系 $x_{i}$ との関係は，基底ベクトル $\boldsymbol{e}_{i}^{\prime}, \boldsymbol{e}_{i}$ を用い $\tau$,

$$
\left.\begin{array}{rl}
\boldsymbol{e}_{i}=Q_{i^{\prime}} \boldsymbol{e}_{j}^{\prime} \\
Q_{i^{\prime}}=\cos \left(\boldsymbol{e}_{i}, \boldsymbol{e}_{j}^{\prime}\right)
\end{array}\right\}
$$

局所座標系における変形速度テンソルとスピン・テン ソルは，Fig.7に示す運動が，領域内で連続であると仮 定し，体積平均を求め，さらにガラスの定理を適用すれ ば,

$$
\left.\begin{array}{l}
D_{11}^{\prime P}=0, \quad D_{12}^{\prime P}=D_{21}^{\prime P}=1 / 2 \dot{\gamma}^{(\alpha)}, \quad D_{22}^{\prime P}=\dot{v}^{(\alpha)} \\
W_{12}^{\prime P}=-W_{21}^{\prime P}=1 / 2 \dot{\gamma}^{(\alpha)}
\end{array}\right\}
$$

と求まる.ここに $\alpha$ は $\alpha$ 番目のすべり運動を示す。'は 局所座標系の成分であることを示す， $\dot{\gamma}^{(\infty)}$ は，すべり面 に沿うせん断ひずみ速度， $\dot{v}^{(\infty)}$ は，すべり面に垂直な方 向の，せん断運動に伴う，体積変化率を示す.

構造主軸と応力主軸が一致する場合には，最大主応力 軸に関して，作用している応力比が同等な 2 つのすべり

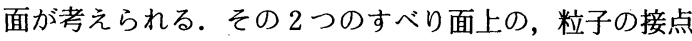

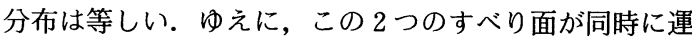
動するという状況を考えることは合理的である。このよ うな場合，スピン・テンソルは，互いに逆の回転速度を 与えるので, その効果は消失する，このことより，構造 主軸と応力主軸の共軸性が成立する場合，スピン・テン ソルは考虑しなくともよいとできる.

すべり面の法線ベクトルを $\boldsymbol{n}$, 接線ベクトルを $\boldsymbol{s}$ と Fig. 7 に示すように表現したとき，式（30）により変換 された，基準座標系 $x_{i}$ での成分は，次のように記述で きる.

$$
\begin{aligned}
& D_{i j}^{p(\alpha)}=P_{i j}^{(\alpha)} \dot{\gamma}^{(\alpha)} \\
& P_{i j}^{(\alpha)}=\frac{1}{2}\left(n_{i}^{(\alpha)} s_{j}^{(\alpha)}+s_{i}^{(\alpha)} n_{j}^{(\alpha)}-2 \tan \nu^{(\alpha)} n_{i}^{(\alpha)} n_{j}^{(\alpha)}\right) \cdots \cdot(33 \cdot \mathrm{a}) \\
& \tan \nu^{(\alpha)}=-\dot{v}^{(\alpha)} / \dot{\gamma}^{(\alpha)} \text {. }
\end{aligned}
$$

式（32），(33）は $\boldsymbol{\alpha}$ 番目のすべり面における運動の

注 5）同じ法線ベクトルを有するすべり面で複数個のすべり が生じている場合，独立に数えることにする。
基準座標系 $x_{i}$ での変形速度に及ぼす寄与を示している. 全体で $N$ 個のすべり運動が生じていれば，全体の変形 速度はその和として，次のように与えることができる．

$$
D_{i j}^{P}=\sum_{\alpha=1}^{N} P_{i j}^{(\alpha)} \dot{\gamma}^{(\alpha)}
$$

式 (34) に基づく具体的な応力ーひずみの計算は，別 の機会に諒り,ここでは,ダイレタンシー挙動のみを考 察する.

式（34）の対角項のみを取り出せば, $\boldsymbol{n} \cdot \boldsymbol{s}=0$ である から

$$
\operatorname{tr}\left(D_{i j}^{P}\right)=D_{k k}^{P}=\sum_{\alpha=1}^{N}-\tan \nu^{(\alpha)} \dot{\gamma}^{(\alpha)}
$$

ここで $\nu^{(\infty)}$ は， $\alpha$ すべり面と，粒子の接触面のなす角で ある。䏠は正のダイレタンシー角を有するときに正に 取る (Fig.7参照)， $\alpha$ すべり面上に作用する垂直応力 成分 $\sigma_{n}^{(\alpha)}$ とせん断成分 $\tau_{s}^{(\alpha)}$ を，それぞれの接点 $\beta$ におけ る接触面に垂直な成分 $\sum_{n}^{(\beta)}$ と接線成分 $\sum_{s}^{(\beta)}$ に分離して, 次式を得る.

$$
\left.\begin{array}{l}
\sum_{s}^{(\beta)} / \sum_{n}^{(\beta)}=\tan \left(\phi^{(\alpha)}-\nu^{(\beta)}\right) \\
\tan \phi^{(\alpha)}=\tau_{s}^{(\alpha)} / \sigma_{n}^{(\alpha)} \\
\tau_{s}^{(\alpha)}=\sigma_{j i} n_{j}^{(\alpha)} s_{i}^{(\alpha)}, \quad \sigma_{n}^{(\alpha)}=\sigma_{j i} n_{j}^{(\alpha)} n_{i}^{(\alpha)}
\end{array}\right\}
$$

式（37）より，負のダイレタンシー角をもった接点の方 が早く,すべりの条件 : $\sum_{s}^{(\beta)} / \sum_{n}^{(\beta)}=\tan \phi_{\mu}$ を満足する ことがわかる.このことより，せん断初期の低応力比状 態では式(35)より,体積圧縮が生ずることが理解できる. 高応力比で，せん断されると，構造は異方的になり，平 均的にすべり面上の接点は，正のダイレタンシー角を有 するようになり，構造変化に引き続いて生ずるすべり運 動は，正のダイレタンシーをもたらすことになる.

次に，一方向に大きくせん断されたときの逆方向載荷 時のダイレタンシー挙動を考える. 本研究で仮定した移 行則の結果（Fig.5）および小西の実験結果（Fig.6）を みると, 逆方向載荷が始まるときの構造は, せん断の影 響を受けて異方的である．このことを逆方向載荷時のす ベり面に適用すると，平均的に負のダイレタンシー角を 有していることがわかる．ゆえに，逆方向載荷時には大 きな体積圧縮が生ずることになる，逆方向載荷時の大き な体積圧縮は，すでにすべり面上の接点の法線ベクトル の分布の変化という観点から, Nemat Nasser ${ }^{13)}$ および Matsuoka \& Takeda ${ }^{14)}$ により説明されている。

注目すべきことは，逆方向載荷時の修正応力比は，初 期より高く，すべりの発生条件に近く，多くのすべり運 動が発生し，せん断ひずみが大きくなることが予想でき ることである.

本研究では，すべり運動による変形速度は，構造変化 が生じ，それに引き続いて生ずると考えていることにな る.つまり，構造変化が砂のような粒状体のひずみ硬化 特性を支配していると考えていることになる，このよう に考えることにより，より合理的に砂の変形挙動が説明 
できることが理解される.

\section{6. 構造主軸と応力主軸が一致しない場合の回 転運動}

初期異方性, 誘導異方性, 主応力回転時の塑性変形挙 動の問題を取り扱う場合には, 前章までの議論とは異な り, 構造主軸と応力主軸の共軸性は成立しないのが一般 的である. 本章の目的は, 共軸性が成立しない場合には， 回転運動が生ずることを明らかにすることである.

いま, 基準座標系として $x_{i}$ をとり, 応力主軸と一致 するものと考える.コンタクト・テンソルの主軸は，プ ライムをつけた座標系 $x_{i}^{\prime}$ にあり, 両者のなす角を $\theta$ と する. 2 階のテンソルの座標変換式 $(37)$ を用いて, $x_{i}$ 系のコンタクト・テンソルを求める (Fig. 8 参照).

$C_{i j}=Q_{i k^{\prime}} Q_{j l^{\prime}} C_{k^{\prime} l^{\prime}}^{\prime}$

さらに, 式（15）より修正応力を求めると, 次のような マトリックスが得られる.

$$
\begin{aligned}
& {\left[\begin{array}{ll}
T_{11}, & T_{12} \\
T_{21}, & T_{22}
\end{array}\right]=\frac{1}{\Delta}\left[\begin{array}{l}
\left(F_{1}^{\prime} \sin ^{2} \theta+F_{2}^{\prime} \cos ^{2} \theta\right) \sigma_{1}, \\
\left(F_{2}^{\prime}-F_{1}^{\prime}\right) \cos \theta \sin \theta \sigma_{1},
\end{array}\right.} \\
& \left(F_{2}^{\prime}-F_{1}^{\prime}\right) \cos \theta \sin \theta \sigma_{2} \\
& \left.\left(F_{1}^{\prime} \cos ^{2} \theta+F_{2}^{\prime} \sin ^{2} \theta\right)_{\sigma_{2}}\right]
\end{aligned}
$$

$\sigma_{2}>\sigma_{1}$ の状態でせん断され， $C_{2}^{\prime}>C_{1}^{\prime}$ の構造になって いるものとすれば, $T_{12}>T_{21}$ であり, Fig. 8 に示すよう に, 構造主軸と応力主軸を一致させるような力として, 作用することがわかる.このような構造主軸の回転は, 粒子の接点の増加が, 最大主軸方向に卓越して生じるこ とによりもたらされるものと考えられる.修正応力には， このような回転運動が表現できる可能性がある.

Table 1 は, Konishi et al. ${ }^{11)}$ の行った初期異方性の強 度に与える影響についての実験結果より，初期状態から 破壊時までに生じた，粒子の接点方向の分布に関する ファブリック・テンソルの主軸の回転量を示している. すべての場合において, 構造主軸と応力主軸のなす角が 減少していることがわかる.

このような構造主軸の回転は, せん断変形に伴う異方 性の発達とともに, 粒状体の変形・破壊挙動に大きな影 響をもつことが考えられる．構造主軸の回転が伴うとき の運動則については, 今後の研究に待たなければならな いがスピン・テンソルが生じる可能性は大きい.

すべり運動を考えてみると, 同じ応力比の作用する面 の構造は, 共軸性が成立しない場合, 異なっており, 同 時に運動したとしても, 両面のせん断ひずみ速度 $\dot{\gamma}$ は 異なり，一般には，スピン・テンソルは消滅しない。一

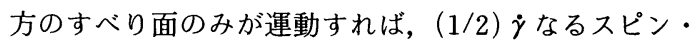
テンソルが生じることになる.

微視的観点から, 構成式を考えていく場合に, 客観性
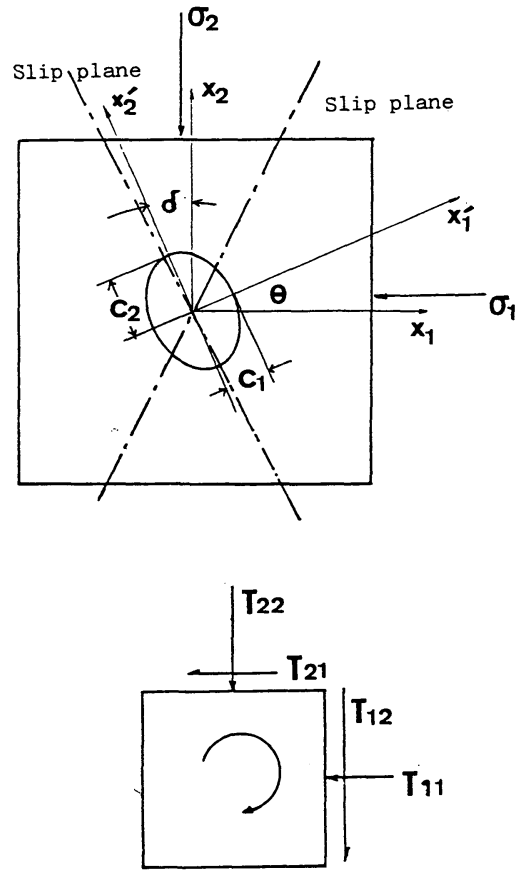

Fig. 8 Rotation of principal axes of fabric tensor in case of

\begin{tabular}{|c|c|c|c|c|c|c|c|}
\hline \multirow{2}{*}{$\left(\frac{\sigma_{2}}{\bar{\sigma}_{1}}\right)_{f}$} & \multirow{2}{*}{$\phi_{\mu}$} & \multirow{2}{*}{$\begin{array}{l}R_{2} \\
\bar{R}_{1}\end{array}$} & \multicolumn{2}{|c|}{$\mathrm{C}_{2} / \mathrm{C}_{1}$} & \multicolumn{2}{|c|}{$\delta$} & \multirow{2}{*}{$\begin{array}{l}\Delta \delta \\
\text { Rota }\end{array}$} \\
\hline & & & Initial & Peak & Ini. & Peak & \\
\hline 11.2 & $52^{\circ}$ & 1.4 & 1.67 & 1.94 & $30^{\circ}$ & $16^{\circ}$ & $14^{\circ}$ \\
\hline 8.2 & $52^{\circ}$ & 1.4 & 1.62 & 1.81 & $44^{\circ}$ & $27^{\circ}$ & $17^{\circ}$ \\
\hline 7.5 & $52^{\circ}$ & 1.1 & 1.67 & 1.71 & $20^{\circ}$ & $4^{\circ}$ & $16^{\circ}$ \\
\hline 7.5 & $26^{\circ}$ & 1.4 & 1.64 & 2.62 & $23^{\circ}$ & $12^{\circ}$ & $11^{\circ}$ \\
\hline 4.3 & $26^{\circ}$ & 1.4 & 1.70 & 1.77 & $42^{\circ}$ & $23^{\circ}$ & $19^{\circ}$ \\
\hline 4.1 & $52^{\circ}$ & 1.1 & 1.14 & 1.36 & $17^{\circ}$ & $5^{\circ}$ & $12^{\circ}$ \\
\hline
\end{tabular}
non-coaxiality between fabrics and stresses.

Table 1 Rotation of fabric principal axes during shear deformation.

Notes; $\varnothing_{\mu}$ : Friction angle of particles, $R_{2} / R_{1}$ : Ratio of the length of major axis to that of minor axis of particles, Other definitions are found in Fig. 8

の原理を満足させるためには，スピン・テンソルに対す る考虑が重要になることが指摘されている ${ }^{15)}$.

本章での議論と関連した問題として, 主応力回転時の 塑性変形挙動について, 構造の観点から考察する. 再び Fig. 8 を参照する. 主軸が固定された状態で， $x_{2}^{\prime}$ 方向に, 最大主応力軸が作用し Fig. 8 に示すような異方的構造が 形成されたものとする. 次に，応力比を一定に保ったま ま, せん断応力 $\tau_{12}=\tau_{21}$, を加えて, 主応力軸を回転させ, $x_{2}$ 軸に最大主応力を作用させる. 明らかに $C_{22}<C_{2}^{\prime}$ で あるから，この応力状態を支えるためには， $x_{2}$ 軸方向 を中心とした構造変化が生じる必要性があり, それに伴 いすべり運動が生じることが考えられる．このように， 異方的な構造の発達という観点から考えれば, 主応力回 
転時の塑性的変形挙動が定性的には理解される.

\section{7. 結 論}

砂のような粒状体の内部構造と内部の微視的応力状態 を反映するコンタクト・テンソルと修正応カテンソルを

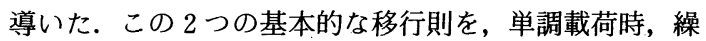
り返し載荷時について提案し, 光弾性粒子を用いた二次 元変形状態の実験結果との比較を行った. また, 変形速 度成分を弾性的成分, 構造変化による成分, 粒子間のす ベりによる成分に分離し, 簡単な関係式を与え, 特に, ダイレタンシー挙動について考察を加えた。本研究での 主要な結果は以下のとおりである.

（1）構造主軸と応力主軸が一致する場合, 応力比と 構造比の関係は, 砂のような粒状体のひずみ硬化機構と 密接に関連し, Oda の実験結果と同一形式である.

（2）修正応力は, ある任意面上の平均的な接触面積 において発揮されるせん断応力比と密接に関連する。ひ ずみ硬化過程においては, 修正応力比 $T_{\max } / T_{\min }$ は, 粒子間摩擦角 $\phi_{\mu}$ で決定される限界值を越えないものと 考えることができる.

（3）コンタクト・テンソルに関する簡単な移行則 (式 (19), (21), (22)) は, 単調載荷時および繰り返 し載荷時の構造変化に関する実験事実と一致する.

（4）本研究で導入した簡単な運動則 (式 (26), (32), (33)）に基づいて,

a ）弾性的変形の載荷時の正のダイレタンシー

b ） 高応力比からの除荷時の体積圧縮挙動

c ）一方向に大きくせん断されたときの, 逆方向載 荷時の大きな体積圧縮挙動

が説明された。

（5）構造主軸と応力主軸が一致しない場合には, 構 造主軸の応力主軸方向への回転が生じることを明らかに し，また，スピン・テンソル成分が一般的には，存在す ることを明らかにした。

本論文は, 砂のような粒状体の内部構造を代表する微 視的要素として, 粒子間接触面積を取り上げ, コンタク ト・テンソルを定義し, これと粒状体の力学的挙動の関 連について考察したものである. 砂のような粒状体の力 学的挙動は, 構成粒子の形状およびその詰まり方により, 大きく変化する.このことは, 単一の微視的要素を取り 出しても, 必ずしも粒状体の力学的挙動は説明できない ことを示唆するものと思われる. ゆえに, 接触面積が, 常に内部構造を反映する第一義的パラメーターではな く, 他の要素, たとえば, 粒子長軸の分布, 間腺比の分 布等が, 変形・破壊挙動を理解するうえで, 第一義的パ ラメーターとなり得る可能性があることを指摘したい.

本研究の成果と, 室内実験で得られる巨視的変形挙動
を結びつけるためには, 対象とする粒状体が著しい不均 質性を有する場合, 均質とみなせる要素に分割し,これ らの要素について何らかの平均化を行う必要があること を付記する.

\section{参 考 文 献}

1) Newland, P. L. and Allely, B. H. : Volume changes in drained triaxial tests on granular materials, Geotechnique, Vol.7, pp. 17 34, 1957.

2) Matsuoka, H. : A microscopic study on shear mechanism of granular materials, Soils and Foundations, Vol. 14, No.1, pp. 29 43, 1974.

3) Horne, M. R. : The behavior of an assembly of rotund, rigid, cohesionless particles Parts 1 \& 2, Proc. Roy. Soc. of London A, Vol.286, pp.62 97, 1965.

4) Oda, M. : Fabrics and their effects on the deformation behavior of sand, 埼玉大学基礎工学研究報告特別号, 1976.

5）小西：砂の様な粒状体の変形・強度挙動に関する微視的 考察, 信州大学工学部報告, 1978.

6) Satake, M. : Fabric tensor in granular materials, Proc. of IUTAM Conference on Deformation and Failure of Granular Materials, Delft, A.A. Balkema, pp. $63 \sim 67$, 1982.

7) Oda, M. et al. : A statistical study of fabrics in a random assembly of spherical granules, Int. Jour. Num. Ana. Methods in Geomechanics, Vol.6, pp. 77 94, 1982.

8) Kanatani, K. : Distribution of directional data and fabric tensors, Int. Jou. Engg. Sci., Vol.22, No. 2, pp.149 164, 1984.

9) Cundall, P.A. et al. : Numerical experiments on granular materials; measurements and obserbations, Proc. of IUTAM Conf. on Deformation and Failure of Granular Materials, Delft, A.A. Balkema, pp. 355 370, 1982.

10) Nemat Nasser, S. and Mehrabadhi, M. : Stress and fabrics in granular mass, Mechanics of granular materials: : New Models and Constitutive Relations, edited by Jenkins and Satake, Elsevier, pp. 1 8, 1983.

11) Konishi, et al. : Inherent anisotropy of assembly of oval cross sectional rods, 科学研究費総合 (B), 粒状 体力学の構成に関する研究, 代表 : 佐武, pp. 33 53, 1982.

12) Oda, et al. : Experimental micro-mechanical evolution of the strength of granular materials: Effects of particle rolling, Mechanics of Granular Materials : New Models and Constitutive Relations, edited by Jenkins and Satake, Elsevier, pp. 21 29, 1983.

13) Nemat Nasser, S. : On behavior of granular materials in simple shear, Soils and Foundations, Vol.20, No. 3, pp. 59 73, 1980.

14) Matsuoka and Takeda: A stress strain relationships derived from microscopic shear mechanism, Soils and Foundations, Vol. 20, No. 3, pp. 45 56, 1980.

15) Nemat Nasser, S. : On finite plastic flow of crystalline solids and geomaterials, Jou. of Applied Mechanics, Vol.50, pp. 1114 1126, 1983. (1984.10.25 - 受付) 